\title{
UNTHEMED
}

\section{Building independent media Sustaining democratic freedoms}

\begin{abstract}
This article examines trends in new media journalism, identifying an independent sector which began to emerge with the internet circa 2000. It finds that publications from initially single-person start-ups like Crikey, to the large circulation New Daily, have proved viable and durable, providing alternatives to mainstream print and broadcast media. They have specialised in politics while publishing also in many other fields, characteristically emphasising user participation in both production and funding and exploiting possibilities of new digital models. This article has case studies of the publications Independent Australia, and the New Zealand-based Asia Pacific Report, to further explain the independents' motivation and mode of operation. It reviews the media environment in two parts: a first phase from 2000 to 2010 and a second major change after 2010 with smart phones and social media. Conclusions are made that the independent sector stands to play a central role in sustaining democracy.
\end{abstract}

Keywords: alternative media, Asia Pacific Report, Australia, Crikey, Independent Australia, independents, internet, journalism, media, new media, New Daily, New Zealand, smart phone, social media

\section{LEE DUFFIELD \\ Media editor, Independent Australia}

\section{Introduction}

-HE ADVENT of the internet has enabled experiments in mass media that can evade the expense and complexities of print and broadcast publishing and challenge the corporate domination of media by opening new channels for more voices. This review of developments in new media concentrates on a segment of independent publications which began to appear around 2000 and have persisted as significant contributors to democratic discourse. That sector has dual interests in maintaining recognised or orthodox principles of ethical journalism and in innovative use of digital communication technology to bring more contributors and participants into the journalistic process. Here the independents as an identifiable sector are treated separately from 'many to many' communication which the internet has enabled, or the expansion of corporate media launched by institutions with primary interests not to do with journalism or publishing. The review also does not cover community broad- 
casting which commenced two decades before the internet, building up to some 300 radio stations in Australia and laying down much essential groundwork in public participation. The community stations are mostly in the strictly local, micro media category, though there are several metropolitan-wide outlets and shared programming on a national network. (CBAA)

This article follows developments from 2000 to 2020, and also employs case studies of Independent Australia and Asia Pacific Report to help demonstrate ways that the sector operates and the thinking of its founders, editors and public. The study notes 27 websites being aggregated under the Independents masthead in Australia. These include The Australian Independent Media Network (AIMN), The Beetoota Advocate, The Big Smoke, Caitlinjohnstone.com, The Chaser, Crikey.com.au, EurekaStreet.com.au, Greenleft.org.au, IndependentAustralia. net, Indigenousx.com.au, Innovationaus.com, Insidestory.org.au, MichaelWest. com.au, TheMonthly.com.au, NewMatilda.com, NewPolitics.com.au, NoFibs. com.au, Pearls and Irritations (John Menadue), Quadrant Online, quillette.com, RenewEconomy.com.au, TheSaturdayPaper.com.au, TheShovel.com.au, Spectator.com.au, TrueCrimeWeekly.com, Thewire.org.au and WomensAgenda.com.au . There are others in New Zealand and the South Pacific. For detailed treatment it selects eight prominent examples: the Asia Pacific Report, Australian Independent Media Network (AIMN) and MichaelWest.com.au, Crikey, Independent Australia, The Monthly, New Matilda, The Saturday Paper and Pearls and Irritations. These or their immediate predecessors emerged in the early period (all founded 2000 to 2010, except Pearls and Irritations 2013 and The Saturday Paper 2014) when would-be independent publishers began with weblogs and moved on to partnership or company arrangements. Some found institutional backing such as a university. The Asia Pacific Report, launched in 2016, was until late 2020 published out of the Pacific Media Centre at Auckland University of Technology (AUT), changing to independent ownership as a Creative Commons outlet in 2021. The Monthly and The Saturday Paper are essentially print outlets but have strong online versions and share many of the key characteristics of the other publications listed.

Two large-circulation titles, The Conversation (launched 2011) and the New Daily (2013) will be added to the discussion. Unlike the earlier ventures they started with advanced production schemes and had large institutional and financial support. Each might be classified with corporate media, except that they offer very comprehensive and differentiated coverage. Their base organisations, respectively universities and industry superannuation funds with associated unions, have a primary, non-commercial interest in broad community engagement.

It will be shown these independents all aim to provide an alternative to so-called mainstream or legacy media, being broadcast, print and their attached digital services. They also stress accessibility for community members 
to contribute and participate in acts of citizen or public journalism. Common characteristics of these publications are that leading personalities with business or journalistic credentials organised the start-ups for these publications, perhaps out of a desire to be seen as social entrepreneurs. An example is Michael West (West, 2019) who runs AIMN, previously a stockbroker and business editor, billed as a 'journalist covering the rising power of corporations over democracy' (West, 2019a). One other example is Eric Beecher, editor-in-chief of Crikey, previously a senior editor at Fairfax and News Corp. (Crikey, 2020) Another is David Robie who as a journalism academic, most recently a journalism professor at Auckland University of Technology, launched a suite of products including Asia Pacific Report, with the goal of advancing human rights, including media freedoms, and providing an independent Asia-Pacific voice, 'telling the untold stories' (Asia Pacific Report, n.d.).

It is a mark of these prime-movers and the publications generally that they are focused on investigative journalism, a field where mainstream publications have pulled back, most often due to cost. The publications also are almost all free of charge, only a few experimenting with revenue pay walls. Preferred sources of income are subscriptions, sponsorships or donations, with marginal help from advertising.

The article takes an historical approach, beginning with the internet coming into full use in 2000, where the Worldwide Web had become available (since 1991), the first website had been launched (The Whitehouse, 1994), and browsers-Microsoft and Netscape - had just arrived (in 1999). (Internet Information, 2019) These developments were an opportunity for independent publishers, which became part of a consolidation of internet-based services generally that was settling in by 2010 - only to then be freshly disrupted by new mobile technology and the advent of social media.

What follows is a review of the publishing experience during the first decade, drawing on treatments of the media environment by Beckett (2018), Flew (2012) and Franklin (2014). The second part of the article addresses the changes in that environment since 2010, with the independent publications weathering change and still developing. It concludes that independent media have proven their model works and are able to offer consistent services and relief to consumers confronted with a confusing, crowded and noisy media environment.

\section{Characteristics of new media ventures 2000-2010}

The explosive development of information and communication technology since 2000 has been a key contributor to sweeping change in mass media which looks to be ongoing, as part of a more general transformation in many aspects of economic, cultural and social life. Franklin (2014, p. 481) points out the striking feature of the process is the fast pace of change as much as its character. 
For mass media it has generated crises of financial viability, and of 'civic adequacy'. He is not optimistic about how numerous, but mostly small operations can surmount such crises. The 'newly emerging participatory, hyperlocal news organisations' he studied in England were 'insufficiently resourced to substitute for the democratic oversight provided by disappearing local papers' (2014, p. 481). Against that was the determination at many levels to provide viable, socially responsible media at a time when the digital communications revolution was getting into its stride.

Such media were typically the 'blogging, citizen journalism and alternative online-only news sites (set up) to present themselves as alternative sources of news journalism in the second half of the 2000s' (Flew, 2012, p. 112-13). By 2012, sites such as OhMyNews in South Korea, Malaysiakini in Malaysia, or New Matilda in Australia, were seen as a developing alternative, with a shared feature of being 'driven by bottom-up citizen journalism and a closer relationship to their reader-contributors.'

\section{Alternatives}

To a degree the founders of these new media were pursuing a creative project for individual and professional purposes. Seizing on low production costs with digital media, which also offered a wide cast for audiences, small operators found they could be a self-sufficient alternative, and an actual minor competitor to major media. Impacts of the same technology which produced these publications, specifically the migration of advertising to the internet, were causing large media outlets to contract. The media outlets would shed staff, skipping many of the labour intensive 'social responsibility' functions of news media- disclosure, informed commentary, challenges to authority - creating something of a vacuum. The notion of providing an alternative was also pro-active, to support reform in society, publish a wider range of views than would appear in the hitherto rationed space of news media, and get out much information - not least information concealed by authority or corporations.

\section{'Bottom-up' engagement}

The dynamics of digital publishing invited the construction of models using a big range of participants including audience members. It would draw heavily on the many to many characteristic of digital communication media, and potentialities of user generated content (UGC); making a key definer of such publications: marshalling of their team, of professional journalists, web producers, marketers and others, or from outside, regular or occasional freelances and stringers, subscribers, donors and contributors of comments.

Among several journalists or observers of the period (2000-2020), Beckett in Supermedia (2008) proposed a scheme of on-going workshops in which 
in-house staff would collaborate with many others on the media product. After a decade, Beckett (2018) said that because of the increased productive power of new technologies he still thought that 'individual journalists or acts of journalism can have more impact than ever before':

I [had] realised [in 2008] that the emergence of new producers such as bloggers and new structures, especially social media, would transform the news media ... It would create more sources and outlets for mainstream journalists, ... increase competition and reduce the power of the news media to act as 'gatekeepers' to information. This came at the same time as a financial crisis for journalism as newspaper sales plummeted and advertising revenue switched to the new online platforms such as Facebook and Google. Journalism was simultaneously feeling threatened and empowered. (Beckett, 2018)

\section{Financial viability}

The fast-developing architecture of a new media ecology could financially hobble big businesses while providing opportunities for smaller operators. Lower cost production for online or mobile had inherent advantages to do with long tail economics, making a wider range of media content potentially profitable, linked with the overall dispersal, demassification and segmentation of the market for it (Flew, 2012, p. 104). The new outlets would develop a mix of 'crowd funding, crowd sourcing and co-creation, with advertising on mobile devices, sale of newspaper apps, hyperlocal business models, not-for-profit models which secure funding from international non-governmental organisations, private foundations and think tanks, plus public funding, sales and subscription to finance minority-language journalism, or efforts to monetise hyperlinks' (Franklin, 2014, p. 484).

Picard (quoted in Franklin, 2014, p. 484), examined the multiple revenue streams, concluding reservedly, 'they provide reason to believe that workable new business models are appearing'.

\section{Professional journalism}

The idea propounded in the 2000s that 'everybody can become a journalist' (Flew, 2013; Duffield \& Cokley, 2006) has been demonstrated by partnerships among journalists and others. The protocols of the news publications, like prioritising of facts, accuracy and discipline with word counts, can be taken up easily. Non-journalists might consider that acquiring journalistic skills can help to optimise their communication competency, including with social media. The ethos of journalism, its culture as understood by Zelizer (2004), or occupational ideology as described by Deuze (2005) is evident in the interest displayed by the new media publications in investigative work or promoting right to know, 
e.g. critical examination of security legislation. Several byline writers from mainstream media are present, whether head-hunted, made redundant or retired from former publications, often themselves financially and professionally set free in the relatively unrestricted new media setting.

\section{Ownership and policies}

The other significant expertise group in the sector is the founder or ownership group. It is common enough for business identities in different fields to want to obtain a media outlet. For example, the Australian mining magnates Lang Hancock (Hancock, 2019) and Peter Wright (Wright, 2019) set up the Perth Sunday Independent in 1969, keeping it going for 15 years. Shareholder activist Stephen Mayne founded Crikey in 2000, stating that:

Stephen campaigns broadly for transparency, good governance and accountability across the media, business and political sectors ...He also ... continues to campaign against the gambling industry. (Stephen Mayne, 2020)

The statement is representative of the policy line of most independent online publications favouring broadly liberal principles.

\section{Finding a market}

Most of the publications focus on politics, which brings in audience numbers, especially during elections, though other fields - arts, environment, the economy, international affairs, general satire, or some sports issues - are also represented. Finding this political niche has enabled them to keep up with the majors, and actually initiate more people into media use. They can also be seen as transitional between first experiments with stand-alone internet publishing, as by individual bloggers, and the later communications outburst set off with smart phones and social media, such as Twitter, Facebook, Google+, Delicious, Pinterest or StumbleUpon.

\section{The developing communications environment after 2010}

By 2010, major media organisations had started to consolidate, through downsizing, multi-media alliances using joint newsrooms and creatively pushing their online incarnations beyond simply shovelling content onto the new platforms. The independent outlets also found their modus operandi as stand-alone websites. But the year 2010 marked the revolutionary new wave of possibilities with mobile telephones and social media. The mass media world was disrupted all over again.

In that year, the four United States multinational online service or computer and software companies that have dominated cyberspace since 
2010 - Google, Amazon, Facebook and Apple — had experienced their dramatic corporate growth spurt and commenced the first rounds of a battle for market share and hegemony (Big Four Tech Companies, 2020). With smart phones for example, in 2010 the Apple iPad and parallel Android devices appeared, and smartphones for the first time outsold personal computers. The following year saw the emergence of a pattern: Apple became the largest smartphone vendor, selling 18.6 million iPhones, just ahead of Samsung's 17.5-million quarterly. A pro tem sorting-out of platforms and devices was achieved through a confusion of major law suits and negotiations involving the software proprietors and main manufacturers led by Apple, Samsung, HTC and Nokia (Arthur, 2012).

In the arena of social media, Facebook has worked since its inception towards its current dominant position. It achieved this in 2011, when it was valued at US $\$ 50$ billion. Its key characteristics had by then been settled: users would be forced to opt in (from 2008), could tag friends (2009), would supply their essential biographic information (2010) and could like comments (2010). (History of Facebook: Timeline, 2020) The short format do-it-yourself publisher Twitter, started in 2006, had 200-million active users by 2013, with 400 million tweets posted daily (Hermida, 2013).

These milestone developments from 2010 became main factors in a global transformation for editors and publishers to navigate - the continuous renewal of information and transmitted communications becoming central to virtually all business or personal life. Where would their publications fit amid the intensified shunting, repurposing, quoting, misquoting and aggregating of alreadypublished material, in a 'chaos of useless information' (Keen, 2011)? Through what psychological defences or other devices might individuals or organisations manage the copious flow?

Negative forces would be thriving by 2020, setting themselves against opportunities for human fulfillment: steadily eclipsing early notions of the internet as a home for free expression, by increasing criminality, harassment and hacking; anxiety about security that imposes limits on information transfer in banking; fake news and hoaxes, related to a widespread fascination with elaborate gaming; intensified monetisation of any information business, not least involving tightened licensing of products, more connectivity, with monitoring, frequent updating and incremental price increases by the software companies; and the burgeoning trade in personal data that has become known as surveillance capitalism.

Sometimes paradoxically, bans and controls on the chaotic internet and mobile telephone services are becoming routinised. These will range from system shut-downs by state authorities during periods of crisis (Access Now, 2018) to administrative control, as in China, blocking-off global services including Wikipedia or Twitter. State interventions will occur, whether for democratic containment of crime or malfeasance, as by the European Union (European 
Commission, 2020); in a continuing search through courts and parliaments for new conceptions, definitions and protection of intellectual property; or through organised cyber assaults, emanating predominently from China and Russia. The character of ongoing developments, good or bad, is unresolved and the pace unrelenting, generating concern about possible impacts. For example, does constant communication-like engagement using mobile devices foreshadow enduring change in the human animal?

In the sea of consequences and competition for attention, there will be more tests for Franklin's (2014) 'civic adequacy' of journalism. As a further paradox, Beckett would conclude (2018) that well-intentioned journalism might yet survive well, if it deploys new media tools to interact closely with many publics, while also deploying the more traditional strengths:

The more reliable and accountable news brands have seen a sharp rise in people consuming their content ... When there is such an abundance of questionable material out there, people often turn to more trustworthy sources. (Beckett, 2018)

\section{Dealing with obstacles and adversity}

The independent outlets have signalled their response to new challenges of the media environment, especially in decrying and publicising state interventions affecting human rights. In Australia these are the federal Acts of Parliament or Regulations described by the journalists' union, the Media Entertainment and Arts Alliance (MEAA, 2019) in a comprehensive report, as 'waves of new laws (which) are passed in the name of "national security" but are really designed to intimidate the media, hunt down whistleblowers, and lock-up information.'

Threats can develop into damaging or fatal events. The decades under review have produced many examples from the South Pacific, where the great distances and lack of other resources, render good communication services even more valuable. (Duffield, Hayes \& Watson, 2008) The smart-phone revolution bypassing telephone or even electricity supply has created unprecedented opportunities for expanded public communication, including new media (Duffield 2020; Watson 2008a; Watson, 2008b). Against that, since 2000 Pacific countries, notably Fiji, Papua New Guinea, Tonga and Vanuatu, have faced periods of tension or active repression against even the largest media outlets - an impediment to setting up independents, for example those wanting to support an opposition movement, or generate development news in communities.

Media control in Fiji travelled beyond raids on newsrooms and maltreatment of journalists, to become formal and ongoing, embodied in the Media Industry Development Decree, renewed in 2013 by the then-insurrectionist Bainimarama government; that government later twice-elected though under a pall of criticism 
to do with media manipulation (O'Sullivan, 2018). On pain of heavy fines, its regulations outlaw any reportage it regards as being against the 'public interest or public order' (Singh, 2015).

If severely inhibiting, the legislation has not killed debate, which is much sustained by the option of online publishing. Main media will still address biting issues, such as in 2021 continuing criticism of the electoral process, carried by The Fiji Times (Rawalai, 2021), responded to through media management (Deo, 2020) and dismissed in ubiquitous government-owned media (The Fijian Government, 2021). Small media operations provide some outlets for dissent, like the official opposition employing social media (Fiji Independent News Service, 2021), or the defiant Truth for Fiji blog (Truth for Fiji, 2021), campaigning against corruption, and against proposed legislation to extend police powers and further militarise the force.

Everywhere, the limited resources of the independents can make them particularly vulnerable to police actions, threats to their cyber security, or vexatious lawsuits. Support of sponsoring organisations can be withdrawn. Events like the COVID-19 pandemic will have a disproportionate impact, where some outlets have reported falling-off of subscriptions or they have been unable to get access to government small business support. The 2021 media bargaining code legislation in Australia, requiring search engines or social media to negotiate payments for product from news producers, saw settlements made among Facebook and Google and the three or four largest media corporations while the smaller organisations were left to catch up in some unbalanced bargaining.

\section{Confidence}

Audience support and involvement is the antidote to danger. Grounds for confidence in the sector are highlighted in an article by Wingerei (2019a), monitoring audiences for the independents in Australia:

Audience growth at michaelwest.com.au (a 67 percent quarterly rise) is part of the broader trend ... while the big four-Sydney Morning Herald, The Age, The Australian and News.com.au - continue to decline in print and battle to get enough subscribers behind their paywalls ... The 27 online sites tracked grew their web traffic numbers by 21.74 percent from February to May 2019, a whopping 33.9 percent compound growth over the last six months. West's growth was fuelled also by the Watergate coverage and other stories covering corporatocracy and tax avoidance.

Crikey is another one of the outstanding performers with 49 percent monthly growth in visits - to 446,000 in May (despite having a paywall) ... Crikey will need that kind of growth to help support the addition of a dozen journalists in their new INQ unit (Inquiry Journalism) (Duke, 2019), but they seem to have found the right balance with their subscription 
model and funding from high net worth individuals Cameron O'Reilly and John Fairfax.

May was, of course, an election month, no doubt adding fuel to the numbers for progressive stalwart Independent Australia.net who had almost 500,000 visits in May... John Menadue's Pearls and Irritations collection of seasoned and diverse commentators also increased its audience by 32 percent... (Wingerei, 2019a)

The Pearls and Irritations outlet, started by John Menadueas as a personal blog in 2013, has 4000 subscribers and 6000 daily readers. (Pearls and Irritations, 2020) It has carried articles from luminaries of the Canberra circuit, such as journalists Jack Waterford and the late Mungo MacCallum and others, including Robert Fisk from the The Independent. Additional figures detailing online readership numbers in February 2019 placed The New Daily with one-million viewers at number 19 among a Top 20 news sites, sharing just under 35 percent of audience in that category with international sites (The Guardian, Daily Mail, BBC, Huffington Post, Buzzfeed). Established in 2013, The New Daily had 446,000 subscribers and more than 2.2 million unique readers a month. Initially funded by Industry Super funds it also attracts advertising which had increased 15 percent in one quarter. The site states it 'proudly aims to improve the financial literacy of all Australians, while keeping them informed on the issues affecting the nation'. Its 17-strong editorial team 'boasts an impressive stable of high-profile commentators' including Quentin Dempster from the ABC and the former Vogue editor Kirstie Clements. (The New Daily, 2018) The Conversation (2019), founded by the CSIRO research institute and four universities in 2011, has succeeded with its research-outreach model, deploying the expertise of university staff (only academics can write for it), with strong institutional funding (from sponsor universities, government, research grants, and reader subscriptions) sustaining 27 editorial staff and more than 70 others and proclaiming journalistic transparency and accountability. It has seven international editions, adding 14.8 million unique users to 5.4 million in Australia. It was the brainchild of a former Observer editor, Andrew Jaspan, and Jack Rejtman, a leader in university business development. For the mainly print publications in the sector, figures for the Saturday Paper identified in a commercial ratings survey (Nielsen Corporation, 2019) gave it a print readership of 439,000 with 165,000 online. For comparison, the total is slightly below the national Seniors publication, (The Senior, 2020) and two to three times the individual totals for regional newspapers (e.g. publications in Albury or Wagga Wagga). In a similar comparison The Monthly, for the September 2019 quarter was included in a bracket of 12 magazines, although the smallest with 171,000 total readership (most often 30,000 per month), after $G Q 309,000$ and Marie Claire 650,000. The Woman's Day title Now to Love was top with 5,149,000.

184 PACIFIC JOURNALISM REVIEW 27 (1 \& 2) 2021 
New Matilda, founded in 2004, has more than 18,000 registered users, of which it claims 90 percent are in professional or senior business roles. It demonstrates some attitude, for example advertising that it will publish any threats made against it, and while imposing the usual prohibitions on defamation or abuse, also excludes any contributions that do not make sense (Newmatilda. com, 2020). New Matilda describes itself as a free source of news, analysis and satire, 'predominantly reader-funded (which) remains fiercely independent...' (Newmatilda.com, 2020a).

Wingerei found strong linkages between independents and social media:

\begin{abstract}
Based on SimilarWeb's data, News.com.au gets 5.5 percent of its visitor traffic from social media, in contrast to The Guardian's 12.2 percent and Independent Australia's almost 20 percent. Overall, independent media gets three to four times more of its visitors referred by social media (mainly Facebook, Twitter and Reddit) than the mainstream news media sites do. (Wingerei, 2019a)
\end{abstract}

See also the comparative circulations from Austin (2019), measuring independent publications as significant minority players in Alexa ratings.

The sketch of audience performance and general characteristics given here highlights opportune aspects of this media genre: drawing significant numbers, managing financially with a variety of revenue sources and trading substantially on political commentary, where most provide long pieces, 600 to 2000 words, offering a good read. Investigative work is favoured and will be paid for, as with the staff increases at Crikey. The business and professional group identified by New Matilda might be a significant part of the audience generally. In places satirical writing and cartoons, as with Independent Australia, indicate an irreverent desire to rock the boat. The adoption of prominent writers goes with an overall savvy business approach, to find and mobilise all kinds of resources. The publications are commonly the inspiration of a founder, as principal editor, working in an entrepreneurial way to ensure the enterprise keeps going.

\title{
Media needs across the South Pacific
}

A special situation applies in the South Pacific due to the dispersal of small, but diverse populations across the blue continent, demanding ingenuity in forming an audience. Global media corporations provide only sparse services, except for one leading contributor not in the independent category - the public broadcaster RNZ Pacific, (RNZ Pacific). That service from Radio New Zealand provides comprehensive coverage throughout its region, but cannot meet the full demand. Radio Australia substantially withdrew after the Australian Broadcasting Corporation dropped shortwave broadcasts in 2017. The online Asia 
Pacific Report was launched in 2016 on models common with independents. It was supported by an institution, the Pacific Media Centre (PMC) within the Auckland University of Technology (AUT) with founder and editor Professor David Robie filling the role of an editorial head and social entrepreneur. It took advantage of new information and communication technology to make innovative products and assembled resources from many parts, including its use in journalism teaching, with student producers and the use of contributions from independent media organisations or universities in far flung communities.

The Asia Pacific Report goes to major media events like summits of the Pacific Islands Forum, although it is prone to put questions outside the usual frame of announcements. In a small sampling of its coverage it gave special attention to the dogged and proud West Papua independence movement, addressed housing shortages in New Zealand, updated the COVID-19 crisis in Papua New Guinea and assessed the Relocation Trust set up for Fijian villages affected by climate change. Naming issues such as climate change, human rights, social justice and sustainable development, it describes itself as a 'critical conscience of society.' (Robie \& Marbrook, 2020; Robie, 2021)

Together with a similar product, Pacific Scoop, founded in 2009 (eventually being relaunched as $A P R$ with more Asia-Pacific content) and the media and rights monitor Pacific Media Watch (in collaboration with Reporters Without Borders), Asia Pacific Report adopted a goal, to 'effectively challenge mainstream gatekeeping media' (Robie, 2016). The proprietary arrangements changed after Robie's retirement from AUT late in 2020 and the closure of the PMC office there (Ellis, 2021), with Asia Pacific Report continuing as a nonprofit joint venture between his publishing company and an independent communications firm, Multimedia Investments Limited, publisher of EveningReport.nz. APR has a unique audience of 110,000 (Google Analytics, 2021). Another PMC publication, Pacific Journalism Review research journal, also continued independently, now edited by Philip Cass with Robie's support.

\section{Independent Australia}

Independent Australia is owned and managed by Dave Donovan on the Queensland Gold Coast, an accountant and business proprietor who discovered a new vocation for journalism and deployed his expertise in both fields to create a viable media outlet. During the publication's first decade, he established the practice of personally checking all items for quality control and probity-'to make sure it was alright'. The enterprise is run by a judicious and opportunistic putting-together of resources: there is multiskilling among the staff of five, attending to production, 'back office' work on subscriptions and donations, video production, and marketing; backed by regular commentators and readercontributors who pitch stories. Donovan, continuing as overall director, has 
handed the managing editor role to Michelle Pini, a journalist with marketing background in Melbourne, the publication now run from the two cities.

Independent Australia invites contributions from writers with established reputations. It also employs cartoonist Mark David, a veteran of mainstream daily newspapers, a kindred spirit who creates the outlet's signature look. $I A$ has published a book, Ashbygate, about the Parliamentary Speaker Peter Slipper and a run of annual magazines.

As a virtual auteur, who stamped his own mark on the product, Donovan resembles several counterparts in the independent field, as does the publication itself, in its restricted scale of operations, high user participation with over 90 contributors, and liberal policy outlook on freedom and authority. The editorial position is flexible, without abandoning inalienable truths, for instance rejecting racist material on moral grounds. He explained the workings of $I A$ in a 2019 interview with this writer (Donovan, 2019), reviewed in March 2021 (Donovan, 2021). Dave Donovan came from a Central Queensland cattle property, studied accountancy and law and worked for investment banks in England, where he began considering journalism instead.

I never really liked accounting and financial analysis. You'd get paid huge amounts of money but you didn't need to do much work, so I did a lot of reading - The Wall Street Journal, The New York Times, The Telegraph. I'd think that it gives you, not a journalism education, but it broadens your experience and understanding of the way the world works: some keys to good journalism. Otherwise, I think your journalism can end up being naïve, a bit shallow, not looking at the undercurrents or context. (Donovan, 2019)

With that classic notion of preparation for journalism, he returned to Australia and took a journalism degree while working with a family firm, Donovan Avocados. Selling that interest, among other undertakings he became media director and vice-chair of the Australian Republican Movement - which led directly to Independent Australia:

I did a lot of freelance work with Fairfax or $\mathrm{ABC}$, and to collate it, found the internet was good for archiving, and I set up a site, also to promote the republic ... Independent Australia started on 24 June 2010 carrying my own journalism and articles on the republic ... It quickly brought in an audience, I guess for both republic topics and my general stories, and we picked up writers like Barry Everingham or Bob Ellis, who I think were sidelined a little by the mainstream media, and Tess Lawrence formerly with the Melbourne Herald Sun.

Soon we were getting something like 400,000 'uniques' a month, largely because I think we provided some investigations that got atten- 
tion, and also there was no-one around really like us ... They all tried a 'false balance', a little bit of this, and that, whereas we were just trying to pursue the truth. If there was something we believed was true, like climate change was real, then we would say that - and I think people respected it. I ended my executive role with the republican movement around 2011, there was a disassociation, $I A$ was able to go pretty much off on its own. (Donovan, 2019)

By 2021, Independent Australia had 2500 subscribers and between 150,000 and 200,000 unique users a week, up to 600,000 monthly, with some fluctuations (including a spike in response to the 2019 elections coverage) 'and a lot more hits'. With annual turnover in the range of $A \$ 400,000$, it was making small profits after 2017, growing at 15 percent a year. That paused with the impact of COVID-19, the operation failing to make any of a projected 17 percent increase. The pandemic had other effects. 'We could not quite 'make' the 30 percent drop in business to qualify for Job Keeper support from the government,' he said. Later he found the negotiations under the media bargaining code legislation (Federal Register of Legislation, 2020) tough going: 'It was really set up for the big corporations. We are getting there slowly but it is out of proportion and in the end it makes us less competitive'. His operation has seen other threats including two lawsuits, though $I A$ has never been in court. Investments in more staff, development of multi-media services (e.g. video, podcasting), or stocking up on merchandise have slowed the ongoing expansion.

Subscriptions, which began in 2015, are the main source of income; costing $\mathrm{A} \$ 50$ to $\mathrm{A} \$ 200$ a year they come with e-mail notifications and merchandise. Growing by 500 in most years, 'with some churn', the subscriptions raise about 50 percent of income. Donations solicited on the site provide some 30 percent, syndicated advertising (via Google and Taboola, and Disqus monitoring comments) raises 10 percent, with additional sources including the merchandise or print publishing.

Donovan is yet to draw a salary, an event postponed also by the pandemic. Staff receive industrial award wages, and contributors a piece rate, based on $\$ 100$ per article, increased depending on readership statistics, which he says is generally accepted as fair. He estimates the value of $I A$ would compare well with Crikey, getting similar readership when sold in 2005 for $\$ 1$ million. 'While I don't get paid, any capital that is raised ... comes to me', he says. He warns against the pitfalls of overwork starting a small business: 'You have to be careful about doing what I did without a significant amount of resources.' As the chief executive he can set policies, but regrets not having time to write:

I don't particularly like writing little short opinion pieces. I prefer actually digging out information that people don't know about. That's the way I 
want $I A$ to go, with more news. I think people are getting beyond wanting to use somebody else's opinion these days. (Donovan, 2019)

An exception is his active work presenting the satirical video, Bloody Idiot of the Week, which with the cartoons is deployed to lighten up the product. The editorial policy emphasises credibility, through transparency, using the internet to provide a fact-checking capability. Like most of the independents, the publication is weighted towards reporting politics or economics. Donovan identified his stance as a 'reaction to neo-liberalism':

We believe in human rights, equality, a strong environment and basically a hybrid or mixed economy, with a decent amount of regulation which protects people - because capitalism like anything left to its own devices will go off the rails ... I don't regard us as being particularly leftwing. (Donovan, 2021)

\section{Conclusions}

The independent publications have made a persuasive case for communitybased journalism, through their persistence over two decades, becoming sustainable operations and building a solid audience base. They have retained conventional journalistic standards such as maintaining fact-based coverage and accountability and apply new technologies adroitly, while depending on active citizen participation in their operations. They provide alternatives to the mainstream, and it might now be argued that the sector can expand to fulfill still more of mass media's obligations towards cultivating democratic life. It would be consistent with the observations of Beckett, that 'individual journalists or acts of journalism can have more impact than ever before'.

Such developments will see the independent sector occupying a place in the plenary zone, a place where all people might go to access trusted media, to obtain properly sourced, essential information and take part in a standing forum on key issues as part of a coherent society. Being able to go there should at least provide relief for individuals from being inundated with surplus information from mobile and online sources. With the help of independent media, there might in fact be much less cause for anxiety that the chaos of the media explosion will become a catalyst for fragmentation and harm to the social order.

\section{References}

Access Now (2018). The state of internet shutdowns across the world: the 2018 \#Keepiton Report. New York, \#KeepItOn Campaign. Retrieved on December 12, 2019, from https://www.accessnow.org/cms/assets/uploads/2019/06/KIO-Report-final.pdf

Arthur, C. (2012). The history of smartphones: Timeline. The Guardian. Retrieved on December 12, 2019, from https://www.theguardian.com/technology/2012/jan/24/ smartphonesAccess Now, -timeline. 
Asia Pacific Report About (n.d.). Asia Pacific Report. Retrieved on March 26, 2021, from https://asiapacificreport.nz/about/

Austin, A. (2019). Where can Australians find trustworthy news and opinion? MichaelWest.com.au. Sydney. Retrieved on November 7, 2020, from https://www.michaelwest.com.au/where-can-australians-find-trustworthy-news-and-opinion/

Beckett, C. (2008). Supermedia: Saving journalism so it can save the world. London, UK: Wiley-Blackwell.

Beckett, C. (2018). The paradox of power for journalists: back to the future of news. London, London School of Economics (LSE). Retrieved from https://blogs.lse.ac.uk/ polis/2018/11/23/the-paradox-of-power-for-journalism-back-to-the-future-of-newsnew-book/

Big Four Tech Companies (2020). Wikipedia. Retrieved on November 17, 2020, from https://en.wikipedia.org/wiki/Big Four tech companies

CBAA, Community Broadcasting Association of Australia, Sydney. Retrieved on March 26, 2021 from https:/www.cbaa.org.au/about/our-members

Crikey (2020a). Eric Beecher: Chairman, Editor-in-Chief. Melbourne. Retrieved on November 17, 2020 from https://www.crikey.com.au/author/ericbeecher/

Crikey. (2020b). Stephen Mayne Journalist and Crikey Founder. Retrieved on November 17, 2020, from https://www.crikey.com.au/author/stephenmayne/

Deo, D. (2020, September 12). Saneem expresses disappointment and confirms email was sent to the Fiji Times. Fiji TV News, Suva. Retrieved from https:/www.fijivillage.com/news/Saneem-expresses-disappointment-and-confirms-email-was-sent-tothe-Fiji-Times-54x8fr/

Deuze, M. (2005). What is journalism? Professional identity and the ideology of journalists reconsidered. Journalism, 6(2), 442-464.

Donovan, D. (2019). Interview with author, Gold Coast, August 8, 2019.

Donovan, D. (2021). Interview with author, Gold Coast, March 21, 2021.

Duffield, L. (2020). Forgetting PNG? Australian media coverage of Papua New Guinea. Pacific Journalism Review: Te Koakoa, 26(1), 178-193. https://doi.org/10.24135/pjr. v26i1.1069

Duffield, L., \& Cokley, J. (Eds.) (2006). I Journalist: Coping with and crafting media information in the 21st century. Sydney, NSW: Pearson.

Duffield, L., Hayes, M., and Watson, A. (2008). Another world : developing countries in the Pacific region need to find their own pathways into the new information society. Convergence, Citizen Journalism and Social Change (pp. 26-28). Singapore: Asia Media Information and Communication Centre (AMIC). Retrieved on March 24, 2021, from https://eprints.qut.edu.au/13158/ | QUT ePrints

Duke, J. (2019). Eric Beecher's Crikey to launch investigative reporting arm, The Sydney Morning Herald, Sydney. Retrieved on November 17, 2020, from https://www.smh. com.au/business/companies/eric-beecher-s-crikey-to-launch-investigative-reportingarm-20190211-p50x0s.html

Ellis, G. (2021, March 30). Pacific Media Centre must break free to survive, Knightly Views. Retrieved on September 5, 2021, from https://knightlyviews.com/2021/03/30/ pacific-media-centre-must-break-free-to-survive/

European Commission (2020). EC digital single market: Social media and networks, innovation and policy. Brussels, European Commission. Retrieved on November 17, 2020, from https://ec.europa.eu/digital-single-market/en/social-media-and-networksinnovation-and-policy

Federal Register of Legislation, Treasury Laws Amendment (News Media and Digital 
Platforms Mandatory Bargaining Code) Bill (2020). Canberra, ACT: Australian Government. Retrieved on March 27, 2021, from https://www.legislation.gov.au/ Details/C2020B00190

Fiji Independent News Service (2020, December 8). Retrieved on March 24, 2021, from https://www.facebook.com/fjindependent/?ref=page_internal

Flew, T. (2012). The digital transformation of 21 st century news journalism. Journal of Communications Management, 13(2), 101-122.

Franklin, B. (2014). The future of journalism. Journalism Studies, 15(5): 481-499. https:// doi.org/10.1080/1461670X.2014.930254

Hancock, L. (2019). Wikipedia. Retrieved on December 30, 2019, from https:// en.wikipedia.org/wiki/Lang_Hancock

Google Analytics (2021). Retrieved on September 5, 2021, from https://analytics.google. com/analytics/web/

History of Facebook: Timeline (2020). Wikipedia. Retrieved on December 29, 2019, from https://en.wikipedia.org/wiki/Timeline_of_Facebook

Hermida, A. (2013). \#Journalism: Reconfiguring journalism research about twitter one tweet at a time, Digital Journalism, 1(3), 295-313.

Independent Australia, (2020a). Barry Everingham. Retrieved on November 17, 2020, from https://independentaustralia.net/profile-on/barry-everingham.

Independent Australia (2020b). Bob Ellis. Retrieved on November 17, 2020, fromhttps://www.bing.com/search?q=bob+ellis+independent+australia\&q$\mathrm{s}=\mathrm{n} \&$ form $=\mathrm{QBRE} \& \mathrm{sp}=-1 \& \mathrm{pq}=\mathrm{bob}+$ ellis + independent + australia\& $\mathrm{sc}=1-31 \& \mathrm{sk}=\&$ cvid=4805087C327146A297FDFB981F0D455C

Independent Australia (2020c). Tess Lawrence. Retrieved on March 24, 2021, from Tess Lawrence (independentaustralia.net)

Independent Media Growth Index. (2019). Retrieved on December 30, 2019, from https:// theindependents.org.au/independent-media-growth-index/

Internet Information. (2019). Retrieved on December 30, 2019 from https://www.informationq.com/about-the-internet/.

Keen, A. (2011). The cult of the amateur. New York, NY: Doubleday.

Media and Entertainment Arts Alliance. (2019). The public's right to know. Sydney. Retrieved on November 17, 2020, from https://www.meaa.org/news/the-publics-right-to-know/

Meade, A. (2020). News Corp announces end of more than 100 Australian print newspapers in huge shift to digital. The Guardian. Retrieved on November 17, 2020, from https://www.theguardian.com/media/2020/may/28/news-corp-announces-end-ofnearly-100-australian-print-newspapers-in-huge-shift-to-digital

Newmatilda. (2020a). Frequently Asked Questions (2020). Retrieved on November 17, 2020, from https://newmatilda.com/faq/.

Newmatilda (2020b). Contact Us. Brisbane. Retrieved on November 17, 2020, from https://newmatilda.com/advertise-us/.

Nielsen Corporation. (2019). Emma Australian total audience report June, September 2019. Macquarie Park NSW, Nielsen Corporation. Retrieved on November 17, 2020, from https://www.emma.com.au/wp-content/uploads/June-19-Total-Audience-Report.pdf

O'Sullivan, D. (2018, November 20). Bainimarama wins again in Fiji, helped by muzzling the media, unions and the church. The Conversation, Melbourne. Retrieved on March 3, 2021, from https://theconversation.com/bainimarama-wins-again-in-fijihelped-by-muzzling-the-media-unions-and-the-church-107192

Pearls and Irritations (2020). John Menadue AO, Sydney. Retrieved on November 7, 2020, from https://johnmenadue.com/precis/. 
Rawalai, L. (2021, March 23). Saneem reports women to FICAC. The Fiji Times. Retrieved on March 24, 2021, from https://www.fijitimes.com.fj/saneem-reportswoman-to-ficac/

RNZ Pacific (2021, March 26). Radio New Zealand. Retrieved March 26, 2021, from https://www.rnz.co.nz/international.

Robie, D. (2016). From Pacific Scoop to Asia Pacific Report: A case study in an independent campus-industry media partnership. Pacific Journalism Review : Te Koakoa, 22(2), 64-86. https://doi.org/10.24135/pjr.v22i2.31

Robie, D. (2021). Asia Pacific Report [Editor] Retrieved March 24, 2021, from https:// asiapacificreport.nz/about/

Robie, D., \& Marbrook, J. (2020). Bearing witness: A Pacific climate crisis documentary and journalism development project. Asia Pacific Media Educator, 30(1), 77-91. https://doi.org/10.1177/1326365X20945417

Singh, S. (2015). FIJI: The evolution of media laws in Fiji and impacts on journalism and society. Pacific Journalism Review : Te Koakoa, 21(1), 126-141. https://doi. org/10.24135/pjr.v21i1.152

Stephen Mayne Journalist and Crikey Founder. (2020) Crikey. Retrieved on November 17, 2020, from https://www.crikey.com.au/author/stephenmayne/

The Conversation: Academic rigour, journalistic flair, (2020). Retrieved on January 30, 2019, from https://theconversation.com/au/ (home)

The Fijian Government. (2021). Suva, Government of Fiji. Retrieved on March 24, 2021, from https://www.fiji.gov.fj/Media-Centre/News

The New Daily (2018). The New Daily 'extremely proud' of record growth. Retrieved on December 30, 2019, from https://thenewdaily.com.au/news/good-news/2018/11/02/ new-daily-record-growth/

The Senior (2020). Tuggerah. Retrieved on November 17, 2020, from https://www. thesenior.com.au/ (home)

The White House (1994). The US Federal Government. Retrieved on March 24, 2021, from https://www.whitehouse.gov/

Truth for Fiji (2021, March). [Blog]. Retrieved on March 24, 2021, from https://www. truthforfiji.com.

Watson, A. (2012a). Mobile phones in Papua New Guinea: Trends and patterns across eight villages. In K. Green, J. Skyes, \& C. Anyanwu (Eds.), Proceedings of the Australian and New Zealand Communication Association Conference: Communicating change and changing communication in the 21st century. Canberra, ACT: Australian and New Zealand Communication Association (ANZCA). Retrieved on March 24, 2021, from https://eprints.qut.edu.au/58322/

Watson A (2012b). Tsunami alert: The mobile phone difference. Australian Journal of Emergency Management, 2(4), 46-50. Retrieved on March 24, 2021, from https:// eprints.qut.edu.au/58318/

West Michael (2019a). Michael West, Independent Australia. Gold Coast. Retrieved on March 29, 2021, from https://independentaustralia.net/profile-on/michael-west,588

West Michael (2019b). @MichaelWest, Twitter. Retrieved on March 29, 2021, from https://twitter.com/MichaelWestBiz?ref_src=twsrc\%5Egoogle $\% 7 C t w c a m p \% 5 E s e r$ $\mathrm{p} \% 7 \mathrm{Ctwgr} \% 5$ Eauthor

Wingerei, K. (2019a). Independent media gathers steam while mainstream struggles: Latest numbers, MichaelWest.com.au. Sydney. Retrieved on November 17, 2020, from https://www.michaelwest.com.au/independent-media-gathers-steam-whilemainstream-struggles-latest-numbers/ 
Wingerei, K. (2019b). Australian independent media on the rise. MichaelWest.com.au. Sydney. Retrieved on December 30, 2019, from https://www.michaelwest.com.au/ australian-independent-media-on-the-rise/

Wright, P. (2019). Biography. Retrieved on December 30, 2019, from http://adb.anu. edu.au/biography/wright-ernest-archibald-peter-15650

Zelizer, B. (2004). Taking journalism seriously: News and the academy. Thousand Oaks, CA: Sage.

Lee Duffield is Independent Australia's media editor. A retired academic and broadcaster, he was the first news editor on the $A B C$ 's youth radio service, TripleJay and was the European correspondent at the fall of the Berlin Wall. He is now an independent researcher and writer with a strong interest in the Pacific.

lee.duffield2@bigpond.com

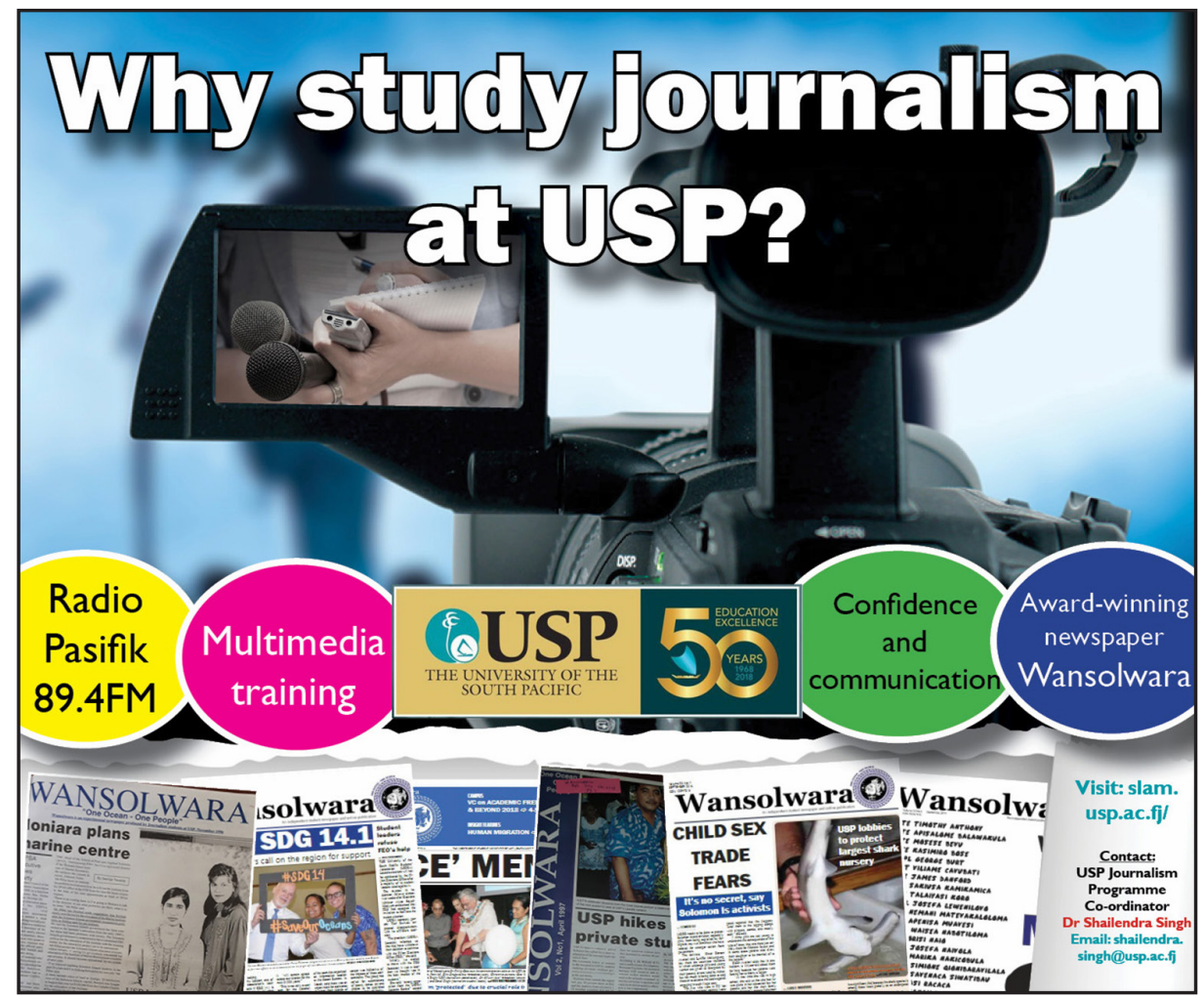

